\title{
Tecer redes, proteger relações: portugueses e africanos na vivência do compadrio (Minas Gerais, 1720-1750)
}

\author{
Moacir Rodrigo de Castro Maia \\ (...) que sabe por ser público e notório que Manuel do \\ Rego Tinoco anda concubinado com uma negra, \\ sua cativa, casada, a qual é sua Comadre. \\ Vila do Carmo (1723) - Diogo de Araújo
}

\section{Introdução ${ }^{1}$}

Desde o final da década de 1980, os estudos sobre escravidão, em particular, sobre a família escrava no Brasil, destacaram a importância do compadrio no cotidiano dos cativos. Constatou-se que o parentesco escravo ia além das relaçóes entre pais e filhos, ultrapassando os laços consanguíneos pelas uniōes com os compadres e suas famílias. Além disso, os estudos que apontaram a importância do compadrio para homens e mulheres escravos acabaram por enterrar a visão de que as senzalas eram promíscuas, ao mesmo tempo que afirmaram a necessidade de (re)criação de parentesco que sentiam aqueles que enfrentaram o cativeiro americano.

As pesquisas sobre a família escrava e o parentesco ritual, celebrado no batismo, reforçaram e consolidaram o entendimento de que escravos e libertos eram agentes na constituição de seus laços familiares, seja na família nuclear, seja nos laços rituais que dela se desdobram. Nesse sentido, o trabalho que Stephen Gudeman e Stuart Schwartz publicaram no final da década 1980, sobre o compadrio na Bahia colonial, trouxe importante contribuição para os estudos sobre o tema e inspirou vários outros trabalhos. ${ }^{2}$

A partir da década de 1990, várias pesquisas privilegiaram principalmente as famílias escravas em diferentes povoações e temporalidades do período colonial e imperial brasileiro. Esses estudos destacaram as realidades vividas pelos cativos, especialmente as distintas escolhas de padrinhos e madrinhas entre livres, escravos e forros, indicando que a presença senhorial como parente ritual era inexistente ou pouco expressiva por ser o estatuto do compadrio conflituoso com o da escravidão: enquanto o primeiro representava proteção, o segundo representava opressão, dominação, como apontado inicialmente por Gudeman e Schwartz. ${ }^{3}$

No entanto, as pesquisas foram desenvolvidas com o foco principal na análise quantitativa de séries paroquiais, particularmente os registros batismais. Nesse sentido, para as análises,

No mais das vezes, tabularam-se as declaraçóes dos nomes dos padrinhos constantes dos registros de batismos, separando-se entre padrinhos livres ou escravos. Eram batizados de escravos, em que havia a preocupação de identificar padrões de escolha de padrinhos, buscando caracterizar uma predominância (ou não) de livres, senhores, forros ou escravos enquanto "pais espirituais", numa tentativa de compreender o processo de socialização do cativo no interior da senzala. ${ }^{4}$

Nesses estudos iniciais, a preocupação com a quantificação e a descrição esbarrou nos limites explicativos dos dados globais. A busca de padróes gerais do compadrio e do apadrinhamento, como bem salientou Carlos Bacellar em 2001, dificultava a apreensão do aspecto social das escolhas individuais. ${ }^{5}$ Dessa maneira, o indivíduo desaparece na grande estrutura dos dados gerais, ou, quando aparece, é para reforçar um "indivíduo médio", representativo de um padrão de escolhas quanto ao padrinho.

Atualmente, a utilização de novos métodos tem aquecido e incentivado as pesquisas das práticas de compadrio no passado colonial e imperial no Brasil. Não basta mais apenas contar! A influência do mé- 
todo microanalítico tem colaborado para instigantes estudos que abordam, por exemplo, a dinâmica e a importância das relações de compadrio em área da fronteira meridional da América Portuguesa. ${ }^{6}$

O presente artigo busca observar algumas novas questōes que claramente destacam a complexidade das relações familiares e cotidianas construídas pela sociedade escravista colonial. Para isso, investigamos os laços de compadrio tecidos em Minas Gerais, na Leal Vila de Nossa Senhora do Carmo (depois cidade de Mariana), na primeira metade do século XVIII, período de sua formação inicial como também de constituição desse novo território. Com essa finalidade, lançamos mão da abordagem microanalítica, essencial para os resultados alcançados.

Com a descoberta de ouro e, posteriormente, de diamantes no interior da América Portuguesa, os sertões das gerais foram sendo ocupados por milhares de colonos, reinóis e escravos de diferentes etnias e regiōes, em sua maioria da África, mas também ameríndios, chineses e "indiáticos".

A situação colonial dessa área em formação moldou as relaçôes afetivas mantidas pelas mulheres escravas, libertas e livres que, pouco a pouco, se estabeleciam no território. A presença diminuta de mulheres cativas em relação ao número de homens escravos é constatada, por exemplo, na cobrança dos direitos reais sobre a extração aurífera. Em 1723, dos 1.239 cativos registrados como moradores da Leal Vila do Carmo, apenas 293 eram do sexo feminino. Se analisarmos as propriedades escravistas, o desequilíbrio de gênero se agrava ainda mais, pois em $35 \%$ das escravarias existia apenas mão de obra masculina e em outras 61 propriedades do Carmo havia apenas uma cativa a trabalhar com outros companheiros. ${ }^{7}$ Alguns anos antes, na paisagem da vizinha Vila Rica, os escravizados do sexo masculino representavam $91 \%$ da população escrava. ${ }^{8}$

Esses dados, comuns na paisagem mineira, especialmente nas primeiras décadas do auge minerador, e em outras áreas coloniais da América Portuguesa, refletiam-se nas dificuldades de acesso do homem escravo ao casamento e a relaçōes afetivas reconhecidas pelos órgãos oficiais. Ao mesmo tempo, esse quadro dava à mulher escrava um leque maior de escolhas na formação de arranjos familiares, especialmente com homens livres. ${ }^{9}$ Das relações tecidas pelas mulheres cativas com livres, libertos e escravos nasceu número significativo de pequenos escravos que povoaram o cenário colonial.

Dessa forma, ao analisar os compadres e também a mãe e o pai das crianças de ventre escravo, o presente artigo sugere a necessidade de se desvendar os arranjos familiares nos núcleos urbanos para se entender as escolhas dos parentes espirituais. Diferentemente das grandes propriedades agrícolas, nas povoações mineiras o cativeiro não condicionava que os casais fossem, necessariamente, cativos. Nesse sentindo, o estudo de caso nos possibilita recuperar outra dimensão que apenas a quantificação da série batismal não abarcaria. Para tanto, há que lançar mão de diferentes fundos documentais, como os paroquiais, notariais, da pequena inquisição e de livros de associaçôes religiosas, à procura de rastros e histórias dos atores sociais, tendo o nome como fio condutor dessa investigação. ${ }^{10}$

Assim, o presente estudo lança luz sobre a trajetória do português Domingos Pinto Machado que, como muitos outros conterrâneos, desembarcou na cidade do Rio de Janeiro para buscar riqueza nas recém-descobertas minas do ouro durante a década de 1710. Quando ainda era ferrador na Leal Vila do Carmo, manteve relação continuada com uma de suas cativas: Joana mina courana que, ao contrário de Domingos Machado, foi embarcada involuntariamente em um dos portos da Baía do Benim, na Costa Ocidental Africana. Dessa relação nasceu a pequena Rita, escrava e filha de Domingos Pinto Machado. As histórias dessas personagens são especiais e, por isso, foram tomadas como fio condutor deste trabalho. Domingos Machado, Joana e Rita foram protagonistas de situações que para nós, quase três séculos depois, evidenciam como os moradores da colônia usavam de variados recursos para fazerem valer suas vontades. Em conjunto, esta análise da relação de compadrio e apadrinhamento traz abordagem diferenciada, ao eleger a rede relacional de um casal formado pelo senhor e sua escrava. Domingos Pinto Machado desempenhava dentre seus vários status os papéis de proprietário de escravos, de pai da filha de uma escrava de sua propriedade, de oficial ferrador, de minerador e, posteriormente, sargento-mor, marido da filha do guarda-mor, entre várias outras "personas" de sua biografia. 
Através dessa trajetória, percebemos como a população de Mariana e de muitas localidades da Capitania, e de fora dela, reinterpretou os significados do compadrio. Muitas vezes, os títulos de padrinho, compadre e comadre eram utilizados para proteger relaçōes amorosas continuadas, transgredindo, assim, antigas normas da Igreja. Além de acompanharmos as transgressões e, consequentemente, as institucionalizações de práticas e usos do chamado compadrio, veremos também a importância desse laço para livres, escravos e para aqueles que conseguiram alcançar a liberdade - o que evidencia como muitos ex-cativos, particularmente africanos, se articulavam e se apropriavam dos diversos signos da sociedade colonial.

Veremos, então, como os laços reforçados no batizado da pequena Rita descortinam as diferentes e complexas redes de sociabilidade construídas nesse território da América Portuguesa.

\section{Tecer redes, proteger relações}

No final de 1726, chegou à Vila do Carmo o primeiro bispo a pisar o solo das Minas Gerais, Dom Frei Antônio de Guadalupe. Era franciscano e bispo da Diocese do Rio de Janeiro, à qual uma grande área da Capitania de Minas Gerais estava submetida. Português, veio dirigir extenso território na América Portuguesa. Tomando posse no Rio de Janeiro, em 1725, no ano seguinte, com 54 anos, frei Guadalupe fez longa viagem com destino ao território mineiro. Ao chegar à Vila do Carmo, foi recebido pelo vigário José Simões, empossado no cargo no início de 1726.

Assim como Dom Frei Antônio de Guadalupe, o vigário do Carmo era nascido no reino. Foi nomeado para as terras do ultramar como primeiro pároco colado da vila mineira. Antes da visita de seu superior, o vigário Simões teve pouco tempo para organizar a igreja de sua nova terra. Desde sua chegada, preocupou-se em regularizar a administração, tanto espiritual como secular, da paróquia que se encontrava em situação difícil após os tumultos causados por seu antecessor, o cônego João Vaz Ferreira.

O cônego fora expulso pelos moradores da Leal Vila de Nossa Senhora do Ribeirão do Carmo, em 1725, em razão de um governo desastroso. A administração irregular dos sacramentos, a tentativa de disciplinar os costumes dos moradores, a cobrança excessiva de propinas e mesmo a pouca disciplina do clero sob sua ordem ocasionaram um dos muitos conflitos vividos nesta parte da colônia portuguesa da América.

Notícias das desordens causadas pelo cônego Vaz chegaram a além-mar, relatadas em carta do governador e dos camaristas ao monarca dom João V:

Na Igreja da Vila de Nossa Senhora do Carmo proveu o Cabido do Rio de Janeiro por vigário a um cônego daquela Sé chamado João Vaz Ferreira, e conservando se naquela igreja mais de dois anos, em todo este tempo sempre andou com os seus fregueses em contendas grandes, porque a todos desprezava com incivilidade e a todos vendia o Sacramento do batismo por duas oitavas de ouro, quando mandavam seus filhos, ou Escravos a batizar, e como o dito Vigário era juntamente Visitador do distrito da sua visita, um grosso cabedal com que Condenava em doze, e treze oitavas de ouro a toda a pessoa, que Se Servia com negras, ou comia Carne na quaresma Sem Fazer ordem de juízo, Se não por uns róis avulsos que mandava Fazer, e estas Condenações mandava cobrar executivamente e como também era Vigário da vara, levava uns Salários exorbitantes, e contra todo o regimento, e Costume, e chegou a tanto o seu excesso e a Sua ambição [...]. ${ }^{11}$

Após o envio da carta ao governador, a situação entre o cônego e seus paroquianos piorou.

[O cônego] mostrou [se] mais desprezador daqueles moradores, e mais fregueses, faltando lhes com o pasto Espiritual, porque não havia missas na Igreja, deixou morrer pessoas sem sacramento por Sua culpa, e mandou crianças para casa sem batismo, por lhe não darem logo duas oitavas de ouro. ${ }^{12}$

Os fregueses do Carmo se revoltaram e, na noite de 15 de fevereiro de 1725, usando máscaras e portando tochas, tentaram invadir a residência do vigário e expulsá-lo da Vila. Contidos os revoltosos, o capitão-mor e oficiais de ordenanças procuraram convencer o cônego a abandonar a freguesia.

O vigário colado Simões, portanto, ao chegar à Vila do Carmo, teve pela frente longo trabalho para reordenar a paróquia, especialmente na regularização da administração dos sacramentos, principalmente 
do batismo e de óbito. Quando o séquito episcopal chegou à Vila, encontrou o pároco colado realizando batizados regulares, principalmente do grande contingente de escravos adultos e de inocentes cativos.

Em sua visita, Dom Frei Antônio de Guadalupe dirigiu-se à população livre da Vila e atacou, especialmente, aqueles que viviam em concubinato. Sua ação faz-se sentir na promoção e divulgação do matrimônio e na inspeção da administração do vigário Simões, de quem elogiou o zelo e cuidado. O bispo do Rio de Janeiro finalizou a visita ao Carmo, oficialmente, em dezembro de 1726. No ano seguinte, o pároco Simóes passou a agir com maior rigor na tentativa de controle da conduta moral dos seus fregueses, principalmente dos homens livres. A partir de 1727, portanto, tornou-se constrangedor assumir, na pia batismal, a paternidade de filho natural de ventre escravo, especialmente da relação entre senhores e escravas.

A ação do bispo Guadalupe em visita ao território mineiro, trabalhando na disseminação do batismo e, em especial, do matrimônio, vinculou-se, segundo Luciano Figueiredo, à reação do Estado e da Igreja às revoltas de Vila Rica e Pitangui, que refletiam a situação instável da colonização de Minas Gerais, ameaçando a dominação colonial. Para o autor, "a expansão das famílias legítimas, peça vital da paz social que deveria sustentar o funcionamento do sistema colonial, passaria desde então a se constituir um dos objetivos centrais da ação do Estado". ${ }^{13}$

Nesse período, encontramos, abrindo uma tenda de ferreiro, Domingos Pinto Machado que, em 1714, instalou-se na freguesia do Carmo e tornou-se oficial mecânico. Aos poucos, diversificando suas atividades, passou a minerar em várias lavras e conseguiu amealhar uma significativa fortuna. Em 1723, havia se tornado possuidor de número expressivo de escravos, 29 cativos, o que representava pertencer ao grupo dos $4 \%$ de senhores da Vila com mais de 20 escravizados. Nos anos posteriores, seu patrimônio continuou a crescer e associou-se a outros mineradores na extração de ouro. Assim, chegou solteiro ao início do ano de 1726, com mais ou menos 35 anos. A eleita para ser sua consorte era filha do guarda-mor Antônio Rodrigues de Souza - e de Maria Leme da Silva -, um dos principais senhores de cativos da região e membro da nobreza da terra, moradores do arraial de Passagem, próximo à Vila. Para um oficial ferrador, o casamento com a filha do guarda-mor, homem encarregado de repartir as datas minerais, seria improvável, mas Domingos Machado, como vimos, lançou-se na mineração com muito êxito e, associando suas duas principais atividades, conseguiu amealhar significativo cabedal. Além disso, no processo de habilitação ao casamento, o ferrador aparece identificado como sargento-mor. Esse enlace mostra que seria equivocado afirmar que um oficial mecânico na América Portuguesa nunca poderia desposar noiva da elite local.

Josefa Rodrigues da Silva havia nascido no Rio de Janeiro e, muito nova, foi com seus pais para as minas do ouro. Quando o bispo Dom Frei Antônio de Guadalupe se encontrava no Carmo, ele autorizou o escrivão e o vigário da Matriz a tomar o depoimento de Josefa em sua moradia:

Josefa Rodrigues da Silva da Cidade do Rio de Janeiro e moradora na Passagem [...] declarou ser a sua idade de treze para quatorze anos e que não tinha feito voto de Castidade, nem de ser Religiosa e que é Contente de fazer este casamento e celebrar este Santo matrimônio sem que para isto fosse Constrangida [...]. ${ }^{14}$

O matrimônio de Domingos Pinto Machado e Josefa Rodrigues da Silva, membros da elite local, foi aprovado e feito sob fiança, pois os comprovantes do noivo só chegariam posteriormente, sendo o processo encerrado em 1731. Assim, eles, com a licença do bispo, casaram-se em 30 de novembro de 1726, na capela de Santa Ana, pertencente à Irmandade de homens brancos, recebendo as bênçãos do vigário Simôes. A cerimônia foi concorrida e contou com muitos moradores de toda a freguesia, além das testemunhas João Fernandes de Oliveira e Francisco da Cunha de Macedo, moradores no arrabalde da Vila, no sítio do Monsus.

João Fernandes de Oliveira e Francisco da Cunha de Macedo eram amigos e vizinhos de Domingos Pinto Machado. Nos banhos matrimoniais, João Fernandes, dizendo-se morador da Vila do Carmo, com 30 anos, deu, a pedido do amigo, seu depoimento e confirmou que conhecia o noivo há nove ou dez anos, e que sempre o conheceu solteiro e sem impedimento algum para casar. Ao se pronunciar sobre a 
noiva, disse que a conheceu nesse mesmo tempo - é possível que João Fernandes tenha chegado nesse período à Vila do Carmo. Domingos ainda teve duas outras testemunhas, Manuel Álvares da Costa, casado e morador na freguesia de Guarapiranga, e Manuel da Silva Lopes, de 35 anos, morador no Carmo.

A amizade entre Domingos Pinto Machado e João Fernandes, havia muitos anos, representava uma forte aliança e, particularmente, sugeria que cada um participava de forma intensa na vida do outro. No casamento de João Fernandes, os papéis se inverteram. A testemunha dos banhos matrimoniais foi o oficial de ferrador e sargento-mor, Domingos, que também foi o fiador do processo. Alguns meses antes, em agosto de 1726, correu o processo matrimonial de João Fernandes de Oliveira com Maria de São José. O amigo Domingos apresentou seu depoimento. Declarou que vivia de minerar - possivelmente, não quis declarar o antigo ofício de ferrador, oficial mecânico -, e que conhecia Fernandes havia dez anos, pouco mais ou menos. Quanto ao costume, isto é, ao vínculo, "disse nada", embora fosse compadre do noivo. ${ }^{15}$

João Fernandes, além de minerador, era homem de negócios e tornou-se um personagem conhecido da história mineira, ao arrendar vários contratos de extração de diamantes no Tejuco. O filho que nascerá do casamento com Maria de São José levará o nome do pai, João Fernandes de Oliveira e será ainda mais conhecido na história mineira, não apenas por administrar os negócios do contrato dos diamantes, mas especialmente por manter relação estável com a ex-escrava Francisca da Silva, conhecida como Chica da Silva, em longo convívio afetivo que frutificou no nascimento de muitos filhos e filhas reconhecidos por João Fernandes. ${ }^{16}$

No entanto, a relação entre Machado e Oliveira já havia se estreitado muito antes, pois Domingos havia convidado João Fernandes para ser padrinho de Rita, sua filha com a escrava Joana mina courana, nascida quando ainda era solteiro, em 1723.

Tal laço foi encoberto por Domingos, ao testemunhar no processo matrimonial do amigo, não declarando que era seu compadre: "do Costume disse nada". Por motivo compreensível, não assumiu o parentesco ritual com o noivo. A proximidade do casamento deste com a filha do guarda-mor era uma forte razão para o ocultamento.

A inocente Rita havia sido batizada na Matriz de Vila do Carmo e, para a celebração do nascimento de sua filha, Domingos, conforme foi dito, elegeu para compadre um vizinho, o minerador João Fernandes de Oliveira, a quem coube a escolha do nome da sua afilhada, por ser devoto de Santa Rita. Portanto, reforçavam-se os laços de convívio. Apenas para destacar a importância da paternidade senhorial em Vila do Carmo, cabe dizer que, naquele ano de 1723, sete senhores assumiram essa condição. Os outros pais declarados eram: sete livres não senhores e apenas quatro escravos. Significa, então, que as crianças escravas nascidas naquele ano eram frutos da relação de mulheres cativas com homens livres. ${ }^{17}$

Diz o registro de batismo:

Rita 1723

Aos vinte e quatro de julho batizou o Padre Marcelo Pinto Ribeiro a Rita filha de Domingos Pinto Machado e de sua escrava Joana, foram padrinhos João Fernandes de Oliveira e Domingos Pinto Machado de que fiz este termo ut supra.

O vigário Matias Gonçalves Neves. ${ }^{18}$

Além do senhor declarar que era pai da pequena Rita e convidar outro homem livre para compadre, ele se tornou padrinho, o que era proibido pelas Constituiçôes Primeiras, não podendo o pai consanguíneo assumir a paternidade espiritual. Uma proibição tão antiga, que remonta ao século IX, indica que o compadrio tinha uma função social importante: buscar a ampliação das relações sociais, dos círculos relacionais. Como foi destacado por Stephen Gudeman, em sua abordagem antropológica sobre relações de parentesco espiritual, os pais eram proibidos universalmente de serem padrinhos dos próprios filhos. ${ }^{19}$ Mais tarde, Stephen Gudeman e Stuart Schwartz, inventariando as práticas de compadrio de escravos no Recôncavo Baiano setecentista, afirmaram, no mesmo sentido, que "de acordo com a lei e a prática da Igreja, os pais nunca eram escolhidos como padrinhos" ${ }^{20}$ 
A leitura da norma eclesiástica universal associada aos limites impostos pela documentação e mesmo a comportamentos familiares regionais, fez com que muitos pesquisadores concluíssem que diferentes populações, no tempo e no espaço, não reinterpretaram a proibição imposta pelo compadrio.

Mesmo com essa proibição, havia suspeitas dessa prática condenada pela Igreja em vários povoados da Capitania de Minas no século XVIII. Diferentemente do ocorrido com Domingos Pinto, que se declarou pai e padrinho, muitos, com medo de serem denunciados por concubinato com suas escravas, tornavam-se compadres das mães de seus filhos e não declaravam a paternidade. Pelas leis da Igreja, os que se uniam pelos laços de compadrio - pais com compadres e afilhados com seus padrinhos - tornavam-se parentes espirituais e, como tal, não poderiam ter intercurso sexual, uma vez que a Igreja condenava essa prática, considerando-a como crime de incesto. Caso os padrinhos e o afilhado, e seus pai e mãe, tanto do batismo quanto do sacramento da confirmação, desejassem o casamento, deveriam pedir licença especial para que a cerimônia pudesse acontecer, pois a cognação espiritual era impedimento dirimente.

Tal delito constava nos editais das visitações que percorriam o território mineiro, lidos pelos párocos nas missas, como aconteceu com o visitador Domingos Luís da Silva, em 1733:

[...] Vigário Colado da Igreja Matriz de N. S. Conceição das Catas Altas, e vizitador nestas minas [...] mando a todas as pessoas, assim eclesiásticas, como seculares, que souberem de pecados públicos, escandalosos, venham perante mim denunciar. [...] cada um dos reverendos lerá a seus fregueses na estação da missa conventual os interrogatórios seguintes. [...] 16. Se alguma pessoa cometeu o crime de incesto, tendo ajuntamento com alguma parenta por consanguinidade, ou afinidade em grau proibido, ou comadre com compadre, ou padrinho com afilhada, ou madrinha com afilhado, e disso haja fama pública. ${ }^{21}$

Foram muitas as visitaçóes que ocorreram no território mineiro durante todo o século XVIII, primeiro sob a jurisdição do Bispado do Rio de Janeiro e, posteriormente, do novo Bispado de Mariana. Os bispos que governaram neste período, e mesmo seus cabidos em caso de sedes vacantes, enviaram continuamente visitadores para as minas. O historiador Luciano Figueiredo encontrou cerca de 53 visitas documentadas de 1721 a 1802 . Afirma o autor:

Para a Igreja - mesmo sob o Padroado - as visitações apareciam como instrumentos de seu poder de julgar. Valendo-se do julgamento de condutas, de uma ação judicial de confronto entre o poder e a prática cotidiana das populações, a Igreja buscava preservar sua legitimidade institucional. A punição com cobranças pecuniárias, excomunhōes, separaçōes, e mais raramente castigos físicos e prisōes, apenas remetia a população ao poder de julgar da Mesa de visitação, instrumento a serviço da Igreja. ${ }^{22}$

Além de revelar a importância do compadrio para os moradores das Minas, particularmente por designar o padrinho do filho como compadre, os livros de testemunhos das devassas eclesiásticas apresentam denúncias de intercurso sexual entre compadres e comadres. Por exemplo, morador na freguesia de Nossa Senhora da Conceição das Congonhas, o capitão Manuel de Souza Freire foi denunciado e pronunciado por este motivo:

ter trato ilícito com Jerônima parda sua escrava com a qual tendo tido o mesmo trato em outro tempo a tomou por sua Comadre e depois de serem Compadres continuam no mesmo trato e tem já dois filhos o que sabe pelo ouvir dizer publicamente por seus vizinhos e que no tempo da quaresma a pôs fora de casa para se haver de se [des]obrigar. ${ }^{23}$

No entanto, os contatos amorosos entre compadres e comadres não eram exclusividade das terras mineiras, pois desde o primeiro século da colonização portuguesa da América se tem notícia da prática do chamado crime de incesto entre parentes espirituais:

Em finais do século XVI, um rico e arrogante senhor de engenho do recôncavo baiano, Fernão Cabral de Ataíde, assediou sua comadre Luísa de Almeida quando ambos se encontravam a sós na capela do engenho. Ela o repeliu, decerto alegando o parentesco mútuo de compadres estabelecido pela Igreja, o que redunda- 
ria em incesto. Mas Fernão chegou a apelar para a intimidação grosseira, nas palavras de Luísa "com grandes juramentos e ameaças e torcendo os bigodes, que se ela não fazia aquela desonestidade ali dentro da igreja, que na força pelasse ele as barbas se ele não tomasse ao dito seu marido e o amarrasse a uma árvore, e perante ele dormisse com ela por força, quando vontade não quisesse". ${ }^{24}$

O compadrio era utilizado por muitos que se encontravam concubinados, na tentativa de proteger suas relações amorosas e, assim, escapar das punições da Igreja em Minas. Na visita empreendida ao território das Minas pelo bispo Guadalupe, citada no início desse texto, essa prática de dissimulação dos casais mineiros aparece no texto de sua Carta Pastoral, lida a cada três meses nas paróquias mineiras, especialmente no ano de 1727. Dom Frei Antônio de Guadalupe repreendia o clero para que não permitisse tais abusos contra a fé:

e porque muitos concubinados para enganarem os Párocos se fazem compadres um do outro, parecendolhes que com esta capa podem viver juntos, mandamos que com estes usem o dito acima e além disso nos batismos não admitam por Padrinhos aquelas pessoas que souberem ficam compadres dos cúmplices do seu delito, pela experiência que temos de que isto é pretexto para continuarem no seu pecado com mais liberdade e maior gravidade e admitindo as tais pessoas serão castigadas a nosso arbítrio. ${ }^{25}$

Em Vila do Carmo, de 1715 a 1750, apenas Domingos declarou ser pai e padrinho de uma filha. Nenhum outro caso foi declarado nas atas batismais encontradas, embora outros pais, possivelmente, tenham sido pais espirituais de seus filhos. Este fato pode nos ajudar a refletir sobre questóes ainda sem explicaçóes, como, por exemplo, os casos, embora residuais, de senhores que se tornaram padrinhos dos filhos de suas escravas. Como destacaram Gudeman e Schwartz, os conflitos de sentidos entre escravidão e apadrinhamento - cativeiro e liberdade -, levaram poucos senhores a se tornarem padrinhos de filhos de seus escravos, embora alguns casos tenham sido relatados. Na localidade por nós privilegiada, de um total de 1.125 atas batismais consultadas, somente 17 senhores apadrinharam filhos de escravas de sua propriedade. Apenas em um caso constava a presença do pai escravo no registro. Em outra situação, o senhor batizou a criança em perigo de morte, e por este motivo, tornou-se seu protetor. As demais atas informam que a mãe aparece sozinha no registro e o padrinho senhor, generosamente, alforria a criança na pia batismal. Esses relatos de extrema liberalidade do senhor ao libertar seus afilhados podem, em alguns casos, significar que o padrinho era, na realidade, pai do inocente escravo, como sugere a relação do ferrador Domingos e a Carta Pastoral do prelado. ${ }^{26}$

A ata de batismo de Rita torna-se, assim, caso excepcional frente aos outros registros que sobreviveram. Ou, conforme Edoardo Grendi, trata-se de um caso excepcional normal ${ }^{27}$ o que a ata verdadeiramente representa, pois diz tanto do fato de o pai se tornar padrinho da própria filha, quanto da prática assumida por determinados casais locais para fugir de possível punição eclesiástica. Esse caso só ganhou destaque e visibilidade em nossa análise ao levantarmos todos os assentos paroquiais de batismo da localidade existentes entre 1715 e 1750 . Em nosso banco de dados, o batizado da pequena Rita é caso único, aparentemente isolado e, nas tabelas sobre os padróes de compadrio e apadrinhamento, muito pouco representaria se tivéssemos adotado uma análise meramente quantitativa.

No início do ano de 1723, Domingos e Joana foram, como muitos outros casais, denunciados em uma devassa eclesiástica. O padre Manuel Francisco afirmou: "Domingos Pinto Machado anda[va] Concubinado com Sua escrava Joana da qual tem uma filha". ${ }^{28}$

Nesse caso, cabe perguntar: por que teria sido permitida a declaração, no assento paroquial, tanto da paternidade quanto do apadrinhamento pelo pai de Rita? Os dados apresentados sobre a paternidade senhorial destacam que as relações tidas como ilegítimas predominavam nessa região. Assim como entre os leigos, no próprio corpo da igreja local, os casos de concubinato eram frequentes. O próprio padre Manuel Francisco foi denunciado, na mesma visitação, por manter relação com uma "preta forra mina”. Além dele, vários clérigos tiveram seus nomes registrados na devassa, inclusive o próprio secretário do processo, o padre Miguel Gomes de Araújo, além do padre Matias Gonçalves Neves, que fez o 
assento de Rita, como também o celebrante do batizado da filha de Domingos, o padre Marcelo Pinto. Embora um número significativo de leigos e de clérigos tenha sido denunciado, outros, como o padre Antônio Jácome, não foram citados, mas confirmaram as relações mantidas pelos irmãos de hábito.

O sínodo reunido na Bahia, do qual resultou a publicação das Constituições Primeiras, foi sensível em relação aos padres e seus filhos e referendou as normas do Concílio Tridentino. Determinava que "[filho] de clérigo de Ordens Sacras, ou Beneficiado, se não batize na pia da Igreja, aonde seus pais foram Vigários, Coadjutores, Curas, Capelães, ou fregueses, mas seja batizada na da freguesia mais vizinha". ${ }^{29}$

O padre Manuel Francisco, no ano anterior à devassa em que foi denunciado e também testemunhou, realizou o batismo de Rosa, sua filha com a escrava Isabel. A criança, batizada em junho de 1722, teve José e Dona Brites Coutinha como padrinhos. O padre Manuel recebeu licença do vigário Miguel Gomes de Araújo para batizar a própria filha na Matriz de Nossa Senhora da Conceição da Vila da Carmo. ${ }^{30}$

\section{Ritos de passagem: casamentos, batismo e enterro}

Quando Rita completou três anos, em 1726, a mãe casou-se com Luís mina, escravo do mesmo senhor. Depois da "missa de Terça”, na Matriz do Carmo, o padre Caetano Lopes de Lima, com a permissão do vigário Simões, celebrou o casamento de Joana e Luís. O noivo, que não consta na listagem de 1723, estaria há menos de três anos morando no sítio do Monsus. As testemunhas do casamento foram João Fernandes de Oliveira e Domingos Pinto Machado "e outras muitas pessoas que aí estavam, todas conhecidas". ${ }^{31}$ Como já foi dito, o senhorio de Joana e Luís casou-se poucos meses depois. A proximidade das datas dos casamentos pode sugerir que Joana casou-se constrangida pelo senhor, para evitar possíveis acusações de concubinato. Percebe-se, por esse fato, que Domingos provavelmente não tenha apenas constrangido Joana a se casar antes dele, mas que ele poderia também ter sido aconselhado a tal ação, pelo pai da noiva ou mesmo por sua vontade em confirmar sua ascensão social pelo matrimônio com Josefa.

Não temos informações sobre a duração do casamento dos cativos do sítio do Monsus, mas o do sargento-mor com a filha do guarda-mor durou bem pouco. Ainda casada, Josefa Rodrigues da Silva fez uma pequena viagem a uma área rural afastada do núcleo urbano da Vila, provavelmente com o marido ou mesmo com o pai. Esteve na fazenda de João Fernandes de Oliveira, no distrito da Vargem do Itacolomi, para o batizado do primeiro filho daquele com a esposa, Maria de São José. Assim, em 9 de junho de 1727, Josefa e Francisco da Cunha de Macedo, vizinho dela nos Monsus, apadrinharam na Capela de Nossa Senhora da Conceição, da fazenda da Vargem, o primogênito de João Fernandes, que recebeu o mesmo nome do pai e será aquele que, no futuro, se tornará conhecido como o contratador dos diamantes ou o "contratador da Chica da Silva". ${ }^{32}$

Encontra-se registrado que o marido de Josefa Rodrigues, Domingos Pinto Machado, foi sepultado no último dia de 1727, no adro, perto da porta principal da Matriz. Portanto, ficaram casados apenas um ano: ela, com apenas quatorze ou quinze anos, já era viúva. Domingos, "morador nas suas lavras do Monsus do nascente", foi morto violentamente, com facadas que lhe deram na cama. ${ }^{33} \mathrm{O}$ vigário Simões e outros clérigos, assim como os escravizados da fazenda, acompanharam o cortejo do corpo do rico sargento-mor do Monsus até a Matriz. Estranhamos a ausência de informação sobre o(a) assassino(a) do pai da pequena Rita. Contudo, o nosso pároco Simões anotou, em ata batismal do ano seguinte, que havia uma criança batizada em necessidade na Cadeia da Vila por nascer "moribunda" de nome Maria, filha de Antônia parda forra "escrava que foi do sargento-mor Domingos Pinto Machado" ${ }^{34}$

Além dessas informações, o vigário também indicou que Domingos teria deixado testamento, sendo testamenteiros o vizinho Francisco da Cunha de Macedo e o compadre João Fernandes de Oliveira. No referido documento, teria disposto vários legados pios. Entretanto, o vigário Simões estava enganado nessas informaçôes, pois o falecido morreu abintestado, isto é, sem deixar testamento.

Após a morte de Domingos, seus bens, como a propriedade do Monsus, foram indiscriminadamente recolhidos pelo Juízo dos Defuntos e Ausentes e colocados em praça pública com o argumento de 
que morrera sem testamento e sem "ter herdeiros na Terra". Mas a rapidez desse Juízo em confiscar a propriedade foi barrada quando Diogo Leite Rebelo, promotor do Juízo dos Órfãos da Vila do Carmo, entrou com o processo, dizendo ser uma afirmação falsa:

agora tem o suplicante notícia que do dito [...] ficara uma filha que teve sendo solteiro de uma sua escrava a qual é menor e chamada Rita; portanto como o tal defunto fosse homem mecânico, e sem dúvida conforme a tê-lo sua Legítima herdeira a dita Rita [...] seja servido nomear tutor a dita órfã [...]. ${ }^{35}$

Com isso, o promotor Diogo Rebelo buscou garantir a herança da pequena Rita. Ocorreu nova movimentação dos vizinhos, impedindo que os bens do falecido Domingos fossem parar nas mãos do juiz dos Ausentes, como arbitrariamente acontecia. Ao referido Juízo cabia a função de recolher os bens dos moradores que morriam sem deixar testamento e sem filhos legítimos, o que gerava uma situação de constrangimento e dificuldades para os órfāos ilegítimos, principalmente filhos de ventre escravo. A mobilização do padrinho tinha o objetivo de garantir a herança da afilhada. Como o pai era oficial mecânico, pessoa sem nobreza, a inocente teria direito à herança, como determinavam as Ordenações Filipinas:

Se algum homem houver ajuntamento com alguma mulher solteira, ou tiver uma só manceba, não havendo entre eles parentesco, ou impedimento, por que não possam ambos casar, havendo cada uma delas filhos, os tais filhos são havidos por naturais. E se o pai for peão, suceder-lhe-ão, e virão à sua herança igualmente com os filhos legítimos, se o pai os tiver. E não havendo filhos legítimos, herdarão os naturais todos os bens e herança de seu pai, salvo a terça, se a o pai tomar, da qual poderá dispor, como lhe aprouver. E isto mesmo haverá lugar no filho, que o homem solteiro peão houver de alguma escrava sua, ou alheia, se por morte de seu pai ficar forro. ${ }^{36}$

Tendo em vista que Machado não teve filhos legítimos de seu casamento com Josefa Rodrigues e era oficial de ferrador, a filha que teve com sua escrava Joana deveria receber a fortuna paterna. Embora o pai tivesse a patente de sargento-mor, o promotor e as testemunhas reforçaram que ele não tinha nobreza. Assim, a sua descendência tinha todos os direitos garantidos. Dessa forma, as testemunhas confirmaram a paternidade. Confirmaram também que, tanto Domingos como a mãe de Rita, eram solteiros quando ela nasceu, sendo que o pai a reconheceu e a tratava como filha.

Nesse processo, apareceram para testemunhar os padres Baltazar de Abreu Novais e Matias Gonçalves Neves, e também o capitão Manuel Ferraz, que viviam de suas ordens. O testemunho do padre Matias Gonçalves Neves, vigário no tempo do batizado, foi muito importante. Segundo ele:

sabia que Domingos Pinto Machado sempre tratara por filha sua, a tal mulatinha Rita, de que se trata e de sua escrava Joana o que sabia por confissões que este lhe fizera várias vezes em público e ainda quando ele dito testemunha fora fazer $o$ termo do assento dos batizados por ser naquele tempo pároco nesta freguesia e [...] lhe perguntado ao dito Domingos Pinto se havia de nomear por sua filha a tal mulatinha ao que lhe respondera [que] fizesse o que quisesse pois [...] nascer[a] em sua casa e que assim consentira que ele testemunha fizesse o assento nomeando a por filha sua e que sabia ele testemunha mais que no tal tempo era o dito Domingos Pinto Machado solteiro e também a tal escrava Joana mãe da tal mulatinha e que o tal Domingos Pinto Machado nunca tivera nobreza alguma mas, sim fora ferrador nesta Vila e que quando se batizara a tal mulatinha Rogara ele para ser padrinho da tal a João Fernandes de Oliveira e ele dito Domingos Pinto fora [o] outro [...]..$^{37}$

O capitão Manuel Ferraz, de 45 anos, morador da Vila, também confirmou os testemunhos anteriores e disse ao juiz dos Órfãos:

que sabia pelo presenciar que o defunto Domingos Pinto Machado batizara sua mulatinha filha de uma sua escrava por nome Joana [...] e ouviu dizer [...] [o] dito Domingos Pinto que era sua filha e a tomou por afilhada com o pretexto de se liberar [...] e que ele testemunha assistiu e outro sim sabe ele testemunha pelo ver que o dito Domingos Pinto exercia ofício de ferrador nesta Vila e depois de minerar com negros seus [...].38 
Domingos, além de convidar o amigo João Fernandes de Oliveira para compadre, foi padrinho de sua filha, para poder libertá-la, embora não tivesse forrado Rita na pia. O plano calculado pelo pai acabou não dando certo, pois não conseguiu dissimular o suficiente para manter a farsa de ser apenas padrinho da criança. ${ }^{39}$ Quanto de incerteza teria marcado o momento do batizado de filhos e afilhados dos demais pais que não aparecem nos registros oficiais, mas que zelavam por sua prole? É pergunta, ainda, sem resposta! Contudo, o que podemos dizer é que os batizados eram momentos de celebração e confraternização, como informa o capitão Manuel, que esteve presente no batizado da filha de seu amigo Domingos. O nascimento dos inocentes era um momento importante para a família, pois reforçava o contato e as relações com parentes e vizinhos, principalmente pela escolha e convite aos padrinhos.

Quando as crianças nascidas eram filhas do senhor e da escrava da casa, geralmente se realizavam "jantares, banquetes", muitas vezes com "gala e fausto". Para Luciano Figueiredo, a celebração do nascimento de filhos naturais "por meio do batismo chegaria a ser um dos principais momentos de confronto entre a ordem legal e a vida cotidiana da população. Festas e trocas afetivas ocorriam fora e no interior da família”. ${ }^{40}$

Em virtude dessas comemorações, que reuniam pais e padrinhos convidados, muitos senhores foram denunciados por concubinato com suas cativas. É o caso de André Fernandes da Silva, que foi acusado por vários moradores da freguesia de São Caetano, pertencente ao termo de Mariana, por celebrar com fausto e gala o nascimento de sua provável filha. Em maio de 1723, o visitador geral das Minas, o cônego João Vaz Ferreira - aquele que, dois anos mais tarde, seria expulso da Vila do Carmo -, achavase em visita à freguesia de São Caetano e mandou publicar os editais da visitação. Foi quando o carpinteiro Francisco de Souza, natural de São Paulo, acusou André da Silva:

tem uma escrava mulher parda chamada Maria em uma venda sua junta e perto de sua vivenda com a qual tem trato ilícito o que sabe por ver continuar ela a casa dele e ele a dela e parindo esta fazer sua festa de banquete e convidar brancos para padrinhos e tratar a criança da dita escrava por sua filha. ${ }^{41}$

As denúncias e denunciantes contra André da Silva continuaram ao longo dos interrogatórios. Pedro Lourenço Veloso, natural do Arcebispado de Braga, que vivia de suas "fazendas de lavras e engenho", também o acusou:

tinha de portas a dentro uma escrava por nome Maria nas Lavras Velhas que de presente se mudou para outra Rosinha junto da qual tem uma filha que por tal apelida e ao padrinho dela Antônio Pires por compadre de que resulta a suspeita e escândalo de ter com ela trato ilícito. ${ }^{42}$

Para além das comemorações pelo nascimento, frente a uma realidade de mortalidade e doenças, a escolha de padrinhos aparece como questão importante para os pais. E suas preferências são especialmente notadas pelas testemunhas que denunciaram aos visitadores eclesiásticos os muitos casais concubinados. Assim, como o ferrador Domingos Pinto Machado, da Vila do Carmo, outros pais livres e senhores interferiram ou atuaram diretamente na escolha dos padrinhos dos seus filhos com suas escravas. Em Mariana, o zelo e cuidado dos homens livres com os filhos nascidos no cativeiro se refletem diretamente nas escolhas dos padrinhos que pertenciam a suas redes relacionais e profissionais. Todos os 61 pais livres, senhores ou não, que aparecem nos livros da Matriz da Vila do Carmo, 1715-1750, tiveram padrinhos do mesmo estatuto social. Foi o que aconteceu com o alferes Santiago. Em dezembro de 1715, entregou Antônio, seu filho com sua escrava Suzana, para ser batizado por Custódio da Silva Serra, capitão-mor da Vila do Carmo, mantendo assim parentesco com uma das principais autoridades da vila. Da mesma forma, o capitão-mor via maximizada a sua esfera de poder e clientela, podendo contar com a fidelidade e gratidão do alferes Santiago. ${ }^{43}$ Não significa isso que todos os homens exercessem a paternidade e o cuidado com os filhos e que as escolhas representassem apenas a interferência paterna. Nem significa também que o cuidado com sua prole representasse situação de segurança e estabilidade familiar para as mães cativas ou mesmo uma relação escravista mais branda com seus escra- 
vos. ${ }^{44} \mathrm{O}$ que queremos ressaltar é que se torna necessário, para os estudos sobre compadrio e família escrava, nas povoações, a investigação do parceiro da mãe escrava, do pai da criança, para que se possa entender a escolha de padrinhos.

\section{Herança de afilhados}

Retomando o caso da herança da pequena Rita, após os testemunhos, foi nomeado como seu tutor Francisco da Cunha de Macedo, minerador, vizinho do falecido Domingos e que tinha sido testemunha do seu casamento com a filha do guarda-mor. Pertencia ao círculo relacional do sargento-mor, juntamente com João Fernandes de Oliveira, o capitão Manuel Ferraz e Manuel da Silva Lopes. A escolha de Francisco de Macedo pelo juiz dos Órfãos levou em conta também que ele era vizinho e, dentre os vizinhos, o mais próspero pertencente ao círculo de amizades do falecido.

Ao assinar o termo de juramento, no mesmo dia das testemunhas que garantiram a herança de Rita, o tutor jurou tratar da menor, defender seus direitos, seus bens e colocá-los “em boa arrecadação". Macedo, "compelido" pela ordem do juiz dos Órfãos, aceitou a tutela, mas pediu procuradores, pois teria de fazer vários requerimentos de cobrança no Juízo dos Ausentes, em Vila Rica, e se encontrava muito ocupado com seus vários negócios e também com "moléstias de saúde". O Juiz aceitou o pedido, mas, em julho do mesmo ano, Francisco de Macedo se disse impossibilitado de zelar pela órfã, pois se achava ocupado com uma mineração no sertão do distrito de Guarapiranga. Nota-se que o tutor, além de vizinho e amigo do falecido Domingos Pinto Machado, era também padrinho de casamento de João Fernandes conjuntamente com a viúva de Domingos. Haveria, além da proteção dos bens da pequena Rita, algum interesse em beneficiar a viúva, filha do guarda-mor? É uma pergunta, ainda, sem resposta.

Ao apresentar a petição, Macedo já estaria acertado com o novo tutor que, no mesmo dia, foi nomeado e prestou o juramento. Tratava-se do padrinho da criança, João Fernandes de Oliveira, que assumiria os seus cuidados e também o de seus bens e que, naquele tempo, morava em Vila Rica, motivo pelo qual o juiz de Órfãos não o escolhera para tutor da afilhada.

A seguir, João Fernandes solicitou que mais testemunhas pudessem dar seu depoimento, provavelmente para garantir que, no futuro, o Juízo dos Defuntos e Ausentes ou mesmo o guarda-mor, pai da esposa do falecido, não protestasse o direito da órfã. Também solicitou ao vigário Simões o termo do registro de batismo de Rita, que comprovava ter sido batizada como filha de Domingos, documento posteriormente anexado ao processo, que também incluía cópia do inventário dos bens, que totalizou mais de 30 contos de réis.

A criança, então com cinco anos, foi morar com o padrinho e sua esposa, Maria de São José, em Vila Rica, na freguesia do Pilar, para onde João Fernandes tinha se mudado, e Rita acompanhou o crescimento da família de João Fernandes. O padrinho, mais tarde, afirmou que a tinha "educado e tratado com toda a honestidade e recolhimento dentro de sua casa com sua mulher e filhos" ${ }^{45}$

A herança do pai foi calculada em 30 contos e 10 tostôes. Esse valor referia-se a 51 cativos, ao sítio do ribeirão do Monsus, à sociedade em uma lavra com o padre Faustino Alves Pereira e, ainda, a duas outras lavras que o pai comprou de Luzia Gonçalves e Manuel Francisco de Souza. Os bens foram vendidos a Gregório Ribeiro de Carvalho, que testemunhou a favor da criança, a pedido de João Fernandes de Oliveira, que teria alguns anos para quitar a compra.

A mãe da pequena Rita, provavelmente, ficou na propriedade do Monsus, próxima ao Ribeiro do Carmo, com o seu marido Luís mina, até a venda da propriedade. Encontramos "Joana preta forra que ficou do defunto Domingos Pinto Machado" em um batizado, na Matriz, como madrinha, em agosto de 1728, um mês depois de seu compadre João Fernandes assumir a guarda de sua filha, o que claramente pode sugerir que ela já se encontrava liberta antes da morte do senhor, ou quando o compadre assumiu os bens da pequena Rita. No início de 1731, o casal Luís Pinto Machado e Joana Pinta assentaram-se como irmãos do glorioso São Benedito e, no mesmo ano, Joana, moradora ainda no Monsus, 
levou à pia batismal sua escrava Teresa mina. A esposa de Luís pertenceu também à Irmandade de Nossa Senhora do Rosário de Mariana e chegou a ocupar, em 1751, o importante cargo de Juíza, sinal de que conseguiu acumular algum pecúlio para poder contribuir com esmolas significativas, obrigação que o posto exigia. Em 1753, segundo consta, morava no Morro de Santo Antônio. ${ }^{46}$

Vê-se, pois, claramente, que as relações de compadrio, portanto, tinham um caráter importante, pois, além de reforçar laços de amizade e consideração, comprovava a aceitação, pelo grupo familiar, dos filhos naturais. $\mathrm{O}$ vínculo estabelecido com o parentesco ritual tornava os participantes, pai e compadre, unidos em uma rede de relações de reciprocidade, de apoio mútuo, principalmente em momentos de dificuldades. Ao mesmo tempo, a legitimação dos filhos naturais, com o recebimento de herança, formaria uma geração mestiça no Império Português, o que colocava em cheque a estabilidade de uma área colonial e reforçava a tensão entre o poder local e o poder da Coroa em disciplinar os comportamentos. ${ }^{47}$

Como a pequena Rita, outros afilhados viveram sob a proteção direta dos padrinhos, como será visto em seguida, o que confirma a manutenção e a importância dos laços para além do ato batismal.

\section{Entre padrinhos e afilhados}

Entre os afilhados que, como Rita, viviam juntos aos padrinhos e suas famílias, houve, em Mariana, o caso de Custódio crioulo, que reforça a importância das relações de compadrio, não só entre livres brancos, mas também entre africanos e descendentes. A preocupação manifestada, nos últimos desejos da preta forra Quitéria Cardoso Leal é bem ilustrativa e reforça a ideia de que as relações firmadas no batismo tinham lugar também nas famílias de ex-escravos. Custódio crioulo tinha doze anos e vivia com o padrinho e sua esposa. $\mathrm{O}$ casal, de bastante idade, temia pelo destino do afilhado, que era também cativo:

Declaro que o Crioulo Custodio que terá de idade doze anos pouco mais ou menos afilhado de meu Marido e por esta Razão o deixo forro e Liberto em condição que por ser muito menino ficará conservado em Companhia do dito até Ser de idade madura, e no caso de Eu e o dito meu Marido falecerem o será conservado na Companhia de meu testamenteiro para ser educado e instruído com Doutrina passando lhe depois carta de alforria e Liberdade. ${ }^{48}$

Em outro caso, Rosa dos Santos, também africana, mesmo não coabitando com a afilhada, preocupava-se com o destino de Maria, parda, filha da comadre Quitéria Pinta, forra. Senhora de escravos, Rosa deixou para Maria, que morava no Ouro Podre, em Vila Rica, uma escrava, Mariana mina. Rosa mina courana era solteira e vivia com o seu irmão Gonçalo dos Santos na ladeira de São Gonçalo. A madrinha, com isso, desejava que a afilhada tivesse uma vida diferente da dela: uma escrava para "ajuda de seu dote sendo que a dita mude de estado e se case dentro em dois anos e sendo caso que se deite a perder dentro no dito tempo, meu testamento tornara a puxar a dita escrava para o monte dos meus bens" ${ }^{49}$

As africanas Quitéria Leal e Rosa dos Santos demonstravam zelo para com o futuro de seus afilhados, sendo que os meninos deveriam ser educados principalmente para um ofício e as meninas preparadas para tomar o estado de casadas. Mas, tanto as afilhadas quanto os afilhados, segundo as protetoras, deveriam seguir os fundamentos da fé cristã, eles aprendendo a doutrina e elas, os deveres de boas esposas.

Antônio da Silva Torres, pardo, seguiu os conselhos de seu padrinho Diogo Ferreira de Souza, morador na rua São Gonçalo, no Arraial de Cima, e aprendeu um ofício. O que o padrinho não imaginava é que seu protegido cuidaria de suas enfermidades ao final da vida, pois tinha aprendido o ofício de barbeiro. Em seu testamento, Diogo de Souza declarou e ordenou a seu testamenteiro: "que se dê a meu afilhado Antônio da Silva Torres pardo e oficial de barbeiro, morador nesta cidade, vinte oitavas de ouro em pó em agradecimento do amor e afeto com que me serviu nas minhas moléstias" ${ }^{50}$

Segundo Ida Lewkowicz, as relações sociais, principalmente de compadrio, construídas pelos libertos e libertas - consolidadas em grande parte por africanos -, no século XVIII, em Minas Gerais, tinham um sentido importante, pois muitos eram solteiros. Forros e forras deixaram suas últimas vontades registradas, legaram bens e quantias, até muitas vezes expressivas, para seus afilhados. ${ }^{51}$ 
Os testamentos deixados pelos moradores dessa localidade mineira, particularmente os documentos que expressavam as vontades finais dos ex-escravos, são provas de que as relações de apadrinhamento se prolongavam para além da cerimônia batismal. Portanto, o vínculo vitalício declarado era vivido na prática por muitos moradores de Mariana.

Outras evidências foram deixadas por senhores que não eram padrinhos, como ocorreu com a preta forra Joana de Oliveira, que também declarou possuir "mais um crioulo por nome Domingos que tem de idade um ano [e] quando os padrinhos do dito crioulo o queiram forrar ou outra qualquer pessoa meus testamenteiros o não impedirão". ${ }^{52}$

Em Mariana, os parentes espirituais participaram algumas vezes, direta e indiretamente, da libertação de filhos de escravas, colaborando muitas vezes com pais que desejavam ocultar a paternidade, e, ao mesmo tempo, libertar sua prole. ${ }^{53}$ Além de ajudar os pais, os compadres e comadres contribuíram com as mães nas negociações para a libertação de seus filhos - nas alforrias onerosas de crianças, os padrinhos foram os principais atores. Fabiana Teixeira, outra senhora preta forra, nos legou uma curta e exemplar história:

[...] até o tempo que a dita Joana minha escrava faleceu e por sua morte veio um filho da dita por nome Vicente cujo tinha sido meu escravo, e em meu poder se forrou com dinheiro que tive por notícias que a Mãe também o dera com pretexto de que a madrinha do dito é que tinha dado o tal ouro tal não foi por testemunhas que o sabem. ${ }^{54}$

A cativa da senhora Fabiana Teixeira apenas obteve a libertação de Vicente quando a madrinha dele conseguiu negociar com a senhora a alforria, o que foi bem mais fácil com os laços de compadrio, tão valorizados para esse fim. Mas a senhora relatou essa pequena história apenas para fazer com que Vicente forro devolvesse a escrava que sua mãe, já falecida, pôde comprar enquanto era cativa de Fabiana Teixeira.

Contudo, a importância do apadrinhamento foi observada também para os escravos adultos, africanos recém-chegados a Vila do Carmo. Ao receberem o batismo cristão, muitos cativos tiveram outros escravos como padrinhos. $\mathrm{Na}$ análise das origens étnicas do amplo número de africanos minas, encontrou-se a evidência de que vários afilhados puderam contar com padrinhos provenientes da mesma terra, falantes da mesma língua, com as mesmas marcas identitárias. A visão de rejeição do batismo deve ser matizada, pois mesmo servindo ao projeto de dominação senhorial, muitos cativos se apropriaram do ritual e construíram ou reforçaram laços de solidariedade com outros conterrâneos. ${ }^{55}$

Esses parentes espirituais tão dedicados refletem o que as práticas de compadrio e apadrinhamento representavam na sociedade mineradora: proteção, cuidado, afeto, convívio, preocupações com o futuro dos inocentes, com a libertação de afilhados e apoio em momentos de doenças. O gesto aponta para o significado tão importante da construção de redes parentais amplas e tão necessárias nas sociedades do Antigo Regime, reproduzindo e alimentando as relações de "reciprocidades hierárquicas" ${ }^{56}$

\section{A afilhada do contratador}

De volta à história da mulatinha Rita e de seu padrinho João Fernandes de Oliveira, a filha de Joana estava com 14 para 15 anos quando, assumindo o sobrenome do pai, passou a ser identificada como Rita Pinta, preparando-se para casar com Domingos Gonçalves Rodrigues, português de 38 anos "pouco mais ou menos". O casamento, provavelmente, foi arranjado por seu padrinho, que escolheu "moço branco, legítimo e trabalhador" para casar com sua afilhada, mulata, com patrimônio significativo. O noivo escolhido morava na Vila do Carmo desde 1726 e também possuía alguns bens: era dono de uma fazenda "de fazer telhas" e possuía vários escravos. Já contratada para casar com o oleiro Domingos Rodrigues, Rita mudou-se para Vila do Carmo no final de 1737. Na Capela de Nossa Senhora da Conceição do Engenho do Monsus, arrabaldes da Vila do Carmo, Rita e Domingos Gonçalves casaram-se no dia 2 de fevereiro de 1738, pelas dez horas da manhã. Além da família de João Fernandes de Oliveira e de sua comadre Joana Pinta, preta forra, "muita gente" se reuniu nesse dia de grande festa no Engenho 
Velho. Como testemunhas, constaram o coronel José de Souza Moura, proprietário da Capela, e o padrinho de batismo e tutor de Rita. ${ }^{57}$

Em 1741, o marido apresentou o pedido para que João Fernandes de Oliveira lhe entregasse os bens da esposa, o que deveria ter acontecido após o casamento. Ao que parece, não houve conflito entre o marido e o padrinho, pois, entre as testemunhas apresentadas por Domingos Rodrigues para assumir os bens da esposa, duas eram parentes de João Fernandes, Manuel e Ventura Fernandes de Oliveira. ${ }^{58}$

Esse fato é revelador do significado dado às alianças firmadas no ato do batismo cristão pelo pai e o padrinho e, possivelmente, pela mãe da criança. O compromisso firmado na pia batismal de benfeitor e protetor da pequena Rita foi assumido, após a morte do pai da menina, pelo padrinho, que assegurou a fortuna da afilhada, como seu tutor. Ela foi morar com a família do padrinho, sendo tratada e cuidada com zelo. O padrinho e tutor, exercendo seu papel de segundo pai, tratou de dar-lhe estado de casada ao escolher um homem livre que pertencia a sua rede clientelar, que mantinha negócios com os Oliveira. O casamento poderia apagar os registros de ilegitimidade de Rita. Embora a afilhada fosse a principal beneficiária das relações estabelecidas no ato batismal, o outro lado também teve ganhos significativos. João Fernandes estreitou suas redes de poder, tendo importante e rico minerador em seu círculo de relações. Com a morte de seu compadre, passou a administrar significativa fortuna, o que obviamente garantia maior prestígio e mesmo ganhos reais na administração dos bens de sua protegida.

\section{Considerações finais}

Por fim, é importante destacar que a instituição do compadrio e apadrinhamento cristão foi vivenciada por moradores da Mariana colonial em diversas condiçôes: livres, forros e escravos. Constituía-se em elemento importante da sociabilidade comunitária, criando-a e recriando-a pela reciprocidade: visitas, convívio, festas, cuidados no momento de doença e também apoio nas necessidades da vida colonial. O compadrio e apadrinhamento também produziam e reproduziam as relaçóes hierarquizadas do Antigo Regime: de um lado o padrinho e do outro a família e o afilhado, hierarquicamente posicionados.

Os vínculos e proximidades que o parentesco ritual reforçava tornavam-se especiais e carregados de valor simbólico. Essas relações foram algumas vezes usadas pelos colonos para protegerem as relações permanentes com suas companheiras: o compadre e a comadre registrados nas fontes setecentistas eram na verdade concubinos. A vivência do compadrio nas vilas coloniais mostra também o cuidado com a prole nascida de relações consensuais, muitas vezes duradouras - geralmente entre senhores e (ex)escravas. Mostra ainda, pelas festas de batizados com "gala e fausto", a importância do convite a padrinhos brancos, no caso do batismo de crianças, e da representação do compadrio com tratamento especial, isto é, chamar de compadre.

Essa história local fragmenta a norma, ou melhor, mostra que havia uma outra norma em construção ou que já se encontrava disseminada nas novas povoações mineiras: a proteção aos filhos, mesmo que fossem escravos, e as relaçôes tecidas com mulheres escravizadas, muitas vezes duradouras. $\mathrm{Na}$ nascente vila, a necessidade de vínculos de parentesco tornou-se fundamental e moldou as estratégias e as relações de interdependências entre os diversos atores sociais. ${ }^{59}$

Além desses aspectos, o batismo da afilhada do contratador João Fernandes de Oliveira revela as formas de solidariedade do compadrio numa sociedade escravista. Com o intuito de libertar a filha e escrava, o senhor torna-se, com seu amigo, padrinho da própria filha, contrariando a norma universal do compadrio. 


\section{Notas}

${ }^{1}$ Este artigo é uma versão modificada e ampliada de capítulo da dissertação “'Quem tem padrinho não morre pagão’: as relaçôes de compadrio e apadrinhamento de escravos numa Vila Colonial (Mariana, 1715-1750)”, (Dissertação de Mestrado, Universidade Federal Fluminense, 2006).

${ }^{2}$ GUDEMAN, Stephen \& SCHWARTZ, Stuart B. Purgando o pecado original: compadrio e batismo de escravo na Bahia do século XVIII. In: REIS, João José (Org.). Escravidão e invenção da liberdade. São Paulo: Brasiliense, 1988, p. 33-59.

${ }^{3}$ Após o importante estudo de Gudeman e Schwartz, podemos destacar, a partir da década de 1990, os seguintes trabalhos: RIOS, Ana Lugão. Família e transição. Famílias negras em Paraíba do Sul, 1872-1920. Dissertação de mestrado apresentada ao Programa de Pós-Graduação em História da UFF. Niterói, 1990; KJERFVE, Tânia Maria G. N. \& BRUGGER, Sílvia Maria. Compadrio: relação social e libertação espiritual em sociedades escravistas (Campos, 1754-1766). Estudos Afro-Asiáticos, n. 20, Jun. 1991, p. 223-238; SLENES, Robert W. Senhores e subalternos no Oeste Paulista. In: NOVAIS, Fernando A. (Coord. Geral) \& ALENCASTRO, Luiz Felipe de (Org. do Volume). História da vida privada no Brasil: cotidiano e vida privada na América portuguesa. São Paulo: Companhia das Letras, vol. 2, 1997, p. 233-290.

${ }^{4}$ BACELLAR, Carlos de A. P. Recuperando sociabilidades no passado. In: BOTELHO, Tarcísio R. et al. História quantitativa e serial no Brasil: um balanço. Goiânia: ANPUH-MG, 2001, p. 33.

${ }^{5}$ Id. Ibid.

${ }^{6}$ HAMEISTER, Martha D. Para dar calor à nova povoação: estudo sobre estratégias sociais e familiares a partir dos registros batismais da vila do Rio Grande (1738-1763). Tese de doutorado apresentada ao Programa de Pós-Graduação em História Social da UFRJ. Rio de Janeiro, 2006. A autora recorre a diferentes tipologias documentais, à bibliografia regional, a estudos de trajetórias, à construção de redes familiares ampliadas, à bibliografia antropológica, pontos fundamentais nos estudos de micro-história, para identificar o compadrio como "herança imaterial" da localidade enfocada.

${ }^{7}$ Reais quintos e lista dos escravos da Vila do Carmo de 1723, AHCMM, cód. 166, fl. 1 a 14. Neste artigo, constam as seguintes abreviaturas: AEAM - Arquivo Eclesiástico da Arquidiocese de Mariana; AHCMM - Arquivo Histórico da Câmara Municipal de Mariana; AHCSM - Arquivo Histórico da Casa Setecentista de Mariana; AHU - Arquivo Histórico Ultramarino.

${ }^{8}$ RUSSELL-WOOD, A. J. R. Escravos e libertos no Brasil colonial. Rio de Janeiro: Civilização Brasileira, 2005, p. 167 (primeira edição de 1984, em inglês).

${ }^{9}$ Não se pode esquecer os constrangimentos e violências senhoriais em ter a escrava de aceitar manter contato amoroso com seu senhor. Por outro lado, ela poderia, em alguns casos, ter calculado os benefícios dessa relação. Algumas vivências no termo de Mariana são bons exemplos dos limites e possibilidades da relação senhor-escrava: "João da Cunha [...] tem de suas portas adentro uma escrava por nome Rosa da qual tem um filho [...] e em certa ocasião [...] não querendo ela tornar para sua companhia andou com ela as pancadas”. Em outra situação João Ribeiro Filgueira mantinha relação continuada com Apolônia, escrava, e os filhos do casal "os tem visto ele testemunha mais bem tratados do que se fossem a escravos e a ela tem visto também bem vestida e calçada”. Testemunho, AEAM, Livro de Devassas 1722-1723 (1), fl. 87-87v.

${ }^{10}$ GINZBURG, Carlo. O nome e o como: troca desigual e mercado historiográfico. In: GINZBURG, Carlo et al. A microhistória e outros ensaios. Lisboa: Difel, 1989, p. 169-178.

${ }^{11}$ Carta de D. Lourenço, governador das Minas Gerais, sobre as desordens causadas pelo cônego João Vaz Ferreira na Vila Rica [sic] do Carmo quando estava por vigário naquela igreja, AHU, cx. 6, doc. 34, cd 2, fl. 1 (grifo nosso).

12 Ibidem (grifo nosso).

${ }^{13}$ FIGUEIREDO, Luciano. Barrocas famílias: vida familiar em Minas Gerais no século XVIII. São Paulo: Hucitec, 1997, p. 25.

${ }^{14}$ Processo de Habilitação Matrimonial, AEAM, n. 1979, arm. 2, pasta 198, fl. 6v.

${ }^{15}$ Processo de Habilitação Matrimonial, AEAM, n. 3608, arm. 3, pasta 361, fl. 4v, 5 e 10v.

${ }^{16}$ FURTADO, Júnia F. Chica da Silva e o contratador dos diamantes: o outro lado do mito. São Paulo: Companhia das Letras, 2003, p. 76. A historiadora Júnia Furtado foi quem primeiro destacou a relação do sargento-mor João Fernandes de Oliveira com seu compadre Domingos Pinto Machado.

${ }^{17}$ Durante os primeiros anos que passou nas Minas, João Fernandes de Oliveira manteve relação afetiva com uma escrava, Lourença Batista. Segundo Júnia Furtado, dessa relação nasceu Teodósio, que o pai mandou estudar cirurgia na França, embora este tenha declarado, em testamento, que duvidava da paternidade, pois a mãe "sempre foi mulher meretriz" - gesto, comum, pois não foram raros os senhores que cuidavam com zelo de prole tida com suas cativas e, ao mesmo tempo, acusavam-nas de meretrizes. FURTADO, Júnia F. Op. cit., p.76. Contudo, sabemos que havia número escasso de mulheres nas Minas e que, em muitas tavernas e mesmo residências, a prática do comércio do corpo era recorrente e representava forma de sustentação para algumas damas.

${ }^{18}$ Registro de Batismo, AEAM, Livro de Batismo O-3, fl. 37. Manteve-se a formatação original do assento. Importante destacar que, para o ano de 1723, 11 atas batismais de crianças escravas não possuem informações sobre a paternidade, num total de 28 registros. 
${ }^{19}$ GUDEMAN, Stephen. Spiritual relationship and selecting a godparent. In: Man, 10, p. 221-222, 1975. Segundo Gudeman, a proibição dos pais poderem assumir o apadrinhamento no batismo (instituída no século IX) viria da pressão e constatação, pelo clero, das práticas sociais de convidar outros indivíduos para patrocinador do ritual e, consequentemente, alargar o número de pessoas envolvidas. A Igreja incorporou, pois, às suas determinaçôes, a prática costumeira das camadas populares. Embora essa nova diretriz estivesse amparada nas vivências de leigos e em suas estratégias de alianças com outros indivíduos fora do núcleo familiar básico, ela não contrariava as noçôes de teologia cristã, que distinguem os laços como naturais, originados do intercurso carnal - consanguíneo ou por aliança - e os laços espirituais, nascidos da recepção do batismo. Teologicamente, no batismo a criança nascida de uma relação carnal, biológica - seria libertada do pecado original e os padrinhos se tornariam os "segundos pais", fiadores da aceitação da fé cristã. Ibidem. A proibição dos pais atuarem como padrinhos foi declarada no Concílio de Munique, em 813, e no Concílio de Metz, em 888, os termos pais e patrocinadores (padrinhos) já aparecem separados. Cf. MINTZ, Sidney \& WOLF, Eric. An analysis of ritual co-parenthood (compadrazgo). In: Southwestern Journal of Anthropology, 6, p. 341-368, 1950.

${ }^{20}$ GUDEMAN, Stephen \& SCHWARTZ, Stuart B. Purgando o pecado original: compadrio e batismo de escravo na Bahia do século XVIII. In: REIS, João José (Org.). Escravidão e invenção da liberdade. São Paulo: Brasiliense, 1988, p. 45.

${ }^{21}$ Apud FIGUEIREDO, Luciano. Op. cit., p. 185-190 (grifo nosso).

22 Ibidem, p. 40-41.

${ }^{23}$ Testemunho, AEAM, Livro de Devassas 1733 (3), fl. 15.

${ }^{24}$ ARAÚJO, Emanuel. A arte da sedução feminina na colônia. In: PRIORE, Mary Del (Org.). História das mulheres no Brasil. São Paulo: Contexto, 1997, p. 53-54.

${ }^{25}$ RODRIGUES (Monsenhor), Flávio Carneiro. Segunda coletânea das visitas pastorais do século XVIII no Bispado de Mariana. Cadernos históricos do Arquivo Eclesiástico da Arquidiocese de Mariana, no 2. Mariana: Editora Dom Viçoso, 2005, p. 13 (grifo nosso).

${ }^{26}$ Segundo Eliana Goldschmidt, em São Paulo, o próprio pai natural tinha sido padrinho de um batizando escravo e, quando este entrou com o processo de habilitação para se casar, ele testemunhou que o filho já tinha sido batizado - pois não foi encontrado o assento batismal, em 1742.

${ }^{27}$ Termo utilizado por Edoardo Grendi: "caracteristicamente, o historiador trabalha sobre muitos testemunhos indiretos: nessa situação o documento excepcional pode resultar excepcionalmente 'normal', exatamente porque revelador”. Apud ESPADA LIMA, Henrique. A micro-história italiana: escalas, indícios e singularidades. Rio de Janeiro: Civilização Brasileira, 2006. p. 451.

${ }^{28}$ Testemunho, AEAM, Livro de Devassas 1722-1723 (1), fl. 45v. Também constam da mesma devassa; Ibidem, fl. 42 a 67; as informaçōes sobre os religiosos no parágrafo seguinte.

${ }^{29}$ CONSTITUIÇÕES Primeiras do Arcebispado da Bahia feitas e ordenadas pelo Ilustríssimo, e Reverendíssimo Senhor D. Sebastiāo Monteiro da Vide $5^{\circ}$ arcebispo do dito Arcebispado, e do Conselho de sua Majestade: propostas, e aceitas em o Sínodo Diocesano, que o dito senhor celebrou em 12 de junho do ano de 1707. $1^{\text {a }}$ edição Lisboa, 1719, e Coimbra, 1720. São Paulo: Typografia 2 de Dezembro de Antônio Louzada Antunes, 1853, p. 16.

${ }^{30}$ Registro de Batismo, AEAM, Livro de Batismo O-3, fl. 31v.

${ }^{31}$ Registro de Casamento, AEAM, Livro de Batismo O-2, fl. 69v.

${ }^{32}$ FURTADO, Júnia F. Op. cit., p. 2003.

${ }^{33}$ Registro de Óbito, AEAM, Livro de Óbito Q-12, fl. 37.

${ }^{34}$ Registro de Batismo, AEAM, Livro O-3, fl. 91v. Quando reconheceu, pelo batismo, em 1723, sua filha com Joana mina, uma de suas cinco escravas, Domingos Pinto Machado tinha um total de 29 escravizados. As mulheres eram predominantemente da chamada Costa da Mina: Catarina cobu, Joana cobu, Joana (mãe de Rita), Antônia mina e Serafina benguela a única cativa proveniente da África Centro-Ocidental.

${ }^{35}$ Inventário de Domingos Pinto Machado (1728), AHCSM, cx. 50, auto 1144, fl. 1 e 2. A ação do Juízo dos Ausentes era periodicamente motivo de queixas à Coroa. Os pais que morriam sem testamento tinham regularmente seus bens confiscados pelo Juízo dos Ausentes, o que impedia muitas vezes os filhos ilegítimos de se tornar herdeiros de seus pais. Assim, havia constante conflito entre famílias e o Juízo dos Ausentes na Capitania mineira. Conferir os protestos do juiz de Órfãos de Sabará, em 1730, estudado por PRAXEDES, Vanda Lúcia. A teia e a trama da 'fragilidade humana': os filhos ilegitimos em Minas Gerais, 1770-1840. Dissertação de mestrado apresentada ao Programa de Pós-Graduação em História da UFMG. Belo Horizonte, 2003, p. 21-22.

${ }^{36}$ ORDENAÇÔES Filipinas, Livro I ao V. Fundação Calouste Gulbenkian, 1985. Título 91, parág. 1, 2 e 3.3 v.

${ }^{37}$ Inventário, AHCSM, cx. 50, auto 1144, fl. 4 e 4v. (grifo nosso).

${ }^{38}$ Ibidem, fl. 4v a 5.

${ }^{39}$ A incerteza que se depreende deste caso mostra, como proposto por Barth, que ela prevalece em toda ação social: "uma das características principais da ação social é que seu resultado depende das ações paralelas, ou da reação, das outras pesso- 
as. Resulta daí uma incerteza quanto às consequências de todo comportamento, a qual é levada em conta pelos indivíduos: ela os impede de contar abstratamente com um sistema de normas para ajudá-los a prever sem ambiguidade os efeitos dos seus atos". Fredrik Barth apud ROSENTAL, Paul-André. Construir o "macro" pelo "micro": Fredrik Barth e a "microstoria”. In: REVEL 1998, p. 157.

${ }^{40}$ FIGUEIREDO, Luciano. Op. cit., p. 119.

${ }^{41}$ Testemunho, AEAM, Livro de Devassas 1722-1723 (1), fl. 86. Os relatos da posse do primeiro Bispo de Mariana, em 1748, enfatizam que, quando os negros escravos que moravam fora da cidade, vinham nos dias santos, durante as comemorações da posse de dom frei Manuel da Cruz, trazer feixes de lenha, colocados na residência episcopal, entravam "pela cidade formados em duas alas, com bandeiras, tambores e instrumentos e cantos a seu modo". Esses comportamentos sugerem que, em muitas comemorações de batizados de filhos de casais escravos, principalmente africanos, as celebrações poderiam ocorrer também a seu modo. Citado por TINHORÃO, José Ramos. As festas no Brasil colonial. São Paulo: Ed. 34, 2000 , p. 112.

${ }^{42}$ Ibidem, fl. 86v.

${ }^{43}$ Registro de Batismo, AEAM, Livro O-2, fl.7.

${ }^{44}$ Casos como o do coronel Salvador Furtado de Mendonça, considerado um dos fundadores da Vila do Carmo, são exemplares. Segundo Lewkowicz, o famoso bandeirante, contemplou em seu testamento tanto os filhos do casamento cristão quanto de sua relação consensual com a mameluca liberta Andresa de Castilho. Por outro lado, o cuidado com as filhas ilegítimas não impedia a relação senhorial muitas vezes extremamente cruel com os escravizados, mesmo ainda jovens. Segundo Bento Furtado, Deve-me mais meu pai o coronel Salvador Fernandes Furtado um rapaz de 12 até 14 anos que me custou 200 oitavas de ouro ao guarda mor Capitão Rodrigues de Souza o qual rapaz morreu de castigo que meu pai lhe mandou fazer. Apud LEWKOWICZ, Ida. Vida em família: caminhos da igualdade em Minas Gerais - século XVIII e XIX. Tese de doutorado apresentada ao Programa de Pós-Graduação em História Social da Usp. São Paulo, 1988, p. 309-310.

${ }^{45}$ Justificação, AHCSM, cód. 301, auto 6130, $1^{\circ}$ Ofício, fl. 1. As novas testemunhas, além de confirmarem as declaraçōes dos primeiros depoentes, reforçaram a relação afetiva que Domingos Pinto Machado tinha com sua filha. João Fernandes, além de convocar três moradores do Carmo, que certamente moravam nos Monsus, procurou um homem de negócios, para dar seu testemunho. Manuel José de Andrade, que vivia de sua venda e tinha 36 anos, disse que, "indo [...] em uma ocasião falar ao defunto [...] a sua casa e achando-o na Sua Lavra ali o viu estar com amor a Rita de que se trata[va] ensinando oraçôes". Gregório Ribeiro, rico minerador, 38 anos, relatou que, indo "uma noite a falar a [...] Domingos [...] e achando-o já recolhido na Cama aí o vira estar com amor [a] Rita de que [a] trata[va] nos braços". Caetano Gazino, "vivia de sua faisqueira, 45 anos, sabia por haver sido Camarada de [...] Domingos [...] a morar com ele junto em uma casa" que Rita era tratada como filha pelo pai. Inventário, AHCSM, cx. 50, auto 1144, fl. 14v.

${ }^{46}$ Respectivamente: Registro de Batismo, AEAM, Livro de Batismo O-4, fl. 21v. Em 1731, ao batizar sua escrava adulta, Teresa mina é listada morando ainda no Monsus. Registro de Batismo, AEAM, Livro O-4, fl. 64v. Assento de Entrada, AEAM, Livro da Irmandade de São Benedito de Mariana P-20, fl. 27v. Registro de Batismo, AEAM, Livro de Batismo O-4, fl. 64v. Assento de Entrada, AEAM, Livro da Irmandade de N. S. do Rosário de Mariana, Livro P-28, fl. 18.

${ }^{47}$ SOUZA, Laura de Mello e. Desclassificados do ouro: a pobreza mineira no século XVIII. Rio de Janeiro: Ediçôes Graal, 2004. (Primeira edição em 1982).

${ }^{48}$ Testamento, AEAM, Livro de Óbito Q-16, fl. 133v a 135v.

${ }^{49}$ Testamento, AEAM, no 1166 , fl. 2v.

50 Testamento, AEAM, Livro de Óbito Q-15, fl. 39.

${ }^{51}$ LEWKOWICZ, Ida. Herança e relações familiares: os pretos forros nas Minas Gerais do século XVIII. Revista Brasileira de História, São Paulo, v. 9 no 17, p. 101-114, set.88/fev.89, p. 109.

${ }^{52}$ Testamento, AHCSM, Livro 63, fl. 1.

${ }^{53}$ As alforrias de inocentes na pia batismal e nos cartórios de Mariana estavam, na maioria das vezes, diretamente ligadas à legitimação dos senhores e pais livres, por relações consensuais com escravas. As mulheres cativas, muitas vezes, mediram os benefícios de suas relações amorosas com os senhores, nem sempre desejadas e consentidas. Mesmo não conseguindo a própria alforria, elas puderam ver seus filhos alforriados e, em alguns casos, com tratamento diferenciado em relação às demais crianças cativas. No entanto, a maioria das alforrias onerosas foi financiada, direta ou indiretamente, pelos padrinhos, o que poderia refletir a importância do compadrio em sociedades escravistas.

54 Testamento, AEAM, Livro de Batismo O-8, fl. $41 \mathrm{v}$.

55 Sobre as relaçôes interétnica e intraétnicas estabelecidas no batismo de escravos adultos em Mariana conferir o estudo: MAIA, Moacir Rodrigo de Castro. O apadrinhamento de africanos em Minas Colonial: o (re)encontro na América (Mariana, 1715-1750). Revista Afro-Ásia, 36 (2007), 39-80.

${ }^{56}$ LANNA, Marcos. A divida divina: troca e patronagem no nordeste brasileiro. Campinas: Editora da Unicamp, 1995, p. $23,198$.

${ }^{57}$ Respectivamente: Processo de Habilitação Matrimonial, AEAM, no 1876, arm. 2, pasta 188; Justificação, AHCSM, cód. 301, auto 6130, 1 Ofício, fl. 1; Registro de Casamento, AEAM, Livro de Casamento O-24, fl. 33v. 
${ }^{58}$ Justificação, AHCSM, cód. 301, auto 6123, 1ํo Ofício. Manuel Fernandes de Oliveira, 31 anos, morador em Águas Claras, freguesia de São Caetano, declarou ter "larga amizade" com Domingos Gonçalves Rodrigues e a outra testemunha, Ventura Fernandes de Oliveira, 32 anos, morando à época na Vila, declarou ter com o marido de Rita "celebrado vários contratos e sempre nele descobriu idoneidade”. Provavelmente, as relações de amizade e negócio de Ventura e Manuel de Oliveira com Domingos Rodrigues foram importantes para a concretização do noivado com Rita.

${ }^{59}$ LEVI, Giovanni. A herança imaterial: trajetória de um exorcista no Piemonte do século XVII. Rio de Janeiro: Civilização Brasileira, 2000.

\section{Referências bibliográficas}

ARAÚJO, Emanuel. A arte da sedução feminina na colônia. In: PRIORE, Mary Del (Org.). História das mulheres no Brasil. São Paulo: Contexto, 1997, p. 45-77.

BACELLAR, Carlos de A. P. Recuperando sociabilidades no passado. In: BOTELHO, Tarcísio R. et al. História quantitativa e serial no Brasil: um balanço. Goiânia: ANPUH-MG, 2001.

CONSTITUIÇÕES Primeiras do Arcebispado da Bahia feitas e ordenadas pelo Ilustríssimo, e Reverendíssimo Senhor D. Sebastião Monteiro da Vide 5o arcebispo do dito Arcebispado, e do Conselho de sua Majestade: propostas, e aceitas em o Sínodo Diocesano, que o dito senhor celebrou em 12 de junho do ano de 1707. 1ㄹ edição Lisboa 1719 e Coimbra. 1720. São Paulo: Typografia 2 de Dezembro de Antônio Louzada Antunes, 1853.

ESPADA LIMA, Henrique. A micro-história italiana: escalas, indícios e singularidades. Rio de Janeiro: Civilização Brasileira, 2006.

FIGUEIREDO, Luciano. Barrocas familias: vida familiar em Minas Gerais no século XVIII. São Paulo: Hucitec, 1997.

FURTADO, Júnia F. Chica da Silva e o contratador dos diamantes: o outro lado do mito. São Paulo: Companhia das Letras, 2003.

GOLDSCHMIDT, Eliana Rea. Compadrio de escravos em São Paulo colonial. Anais da VIII Reunião da Sociedade Brasileira de Pesquisa Histórica (SBPH). São Paulo, 1989, p. 81-83.

GUDEMAN, Stephen. Spiritual relationship and selecting a godparent. Man, 10, 1975, p. 221-222.

GUDEMAN, Stephen \& SCHWARTZ, Stuart B. Purgando o pecado original: compadrio e batismo de escravo na Bahia do século XVIII. In: REIS, João José (Org.). Escravidão e invenção da liberdade. São Paulo: Brasiliense, 1988, p. 33-59.

GINZBURG, Carlo. O nome e o como: troca desigual e mercado historiográfico. In: GINZBURG, Carlo et al. A micro-história e outros ensaios. Lisboa: Difel, 1989.

HAMEISTER, Martha D. Para dar calor à nova povoação: estudo sobre estratégias sociais e familiares a partir dos registros batismais da vila do Rio Grande (1738-1763). Tese de doutorado apresentada ao Programa de Pós-Graduação em História Social da UFRJ.

LANNA, Marcos. A divida divina: troca e patronagem no nordeste brasileiro. Campinas: Editora da Unicamp, 1995.

LEVI, Giovanni. A herança imaterial: trajetória de um exorcista no Piemonte do século XVII. Rio de Janeiro: Civilização Brasileira, 2000.

LEWKOWICZ, Ida. Vida em familia: caminhos da igualdade em Minas Gerais - século XVIII e XIX. Tese de doutorado apresentada ao Programa de Pós-Graduação em História Social da Usp. São Paulo, 1988.

. Herança e relações familiares: os pretos forros nas Minas Gerais do século XVIII. Revista Brasileira de História, São Paulo, v. 9 no 17, set.88/fev.89, p. 101-114.

MAIA, Moacir Rodrigo de Castro. O apadrinhamento de africanos em Minas Colonial: o (re)encontro na América (Mariana, 1715-1750). Afro-Ásia, 36 (2007), p. 39-80.

MINTZ, Sidney \& WOLF, Eric. An analysis of ritual co-parenthood (compadrazgo). Southwestern Journal of Anthropology, 6, p. 341-368, 1950.

KJERFVE, Tânia Maria G. N. \& BRUGGER, Sílvia Maria. Compadrio: relação social e libertação espiritual em sociedades escravistas (Campos, 1754-1766). Estudos Afro-Asiáticos, no 20, jun. 1991, p. 223-238.

ORDENAÇÕES Filipinas, Livro I ao V. Fundação Calouste Gulbenkian, 1985. 3 v. 
PRAXEDES, Vanda Lúcia. A teia e a trama da "fragilidade humana": os filhos ilegitimos em Minas Gerais, 17701840. Dissertação de mestrado apresentada ao Programa de Pós-Graduação em História da UFMG. Belo Horizonte, 2003.

ROSENTAL, Paul-André. Construir o "macro" pelo "micro": Fredrik Barth e a "microstoria". In: REVEL, Jacques (Org.). Jogos de escalas. Rio de Janeiro: FGV, 1998.

RIOS, Ana Lugão. Família e transição. Famílias negras em Paraíba do Sul, 1872-1920. Dissertação de mestrado apresentada ao Programa de Pós-Graduação em História da UFF. Niterói, 1990.

RODRIGUES (Monsenhor), Flávio Carneiro. Segunda coletânea das visitas pastorais do século XVIII no Bispado de Mariana. Cadernos históricos do Arquivo Eclesiástico da Arquidiocese de Mariana 끌. Mariana: Editora Dom Viçoso, 2005.

RUSSELL-WOOD, A. J. R. Escravos e libertos no Brasil colonial. Rio de Janeiro: Civilização Brasileira, 2005. (primeira edição de 1984, em inglês).

SLENES, Robert W. Senhores e subalternos no Oeste Paulista. In: NOVAIS, Fernando A. (Coord. Geral) \& ALENCASTRO, Luiz Felipe de (Org. do Volume). História da vida privada no Brasil: cotidiano e vida privada na América portuguesa. São Paulo: Companhia das Letras, 1997, vol. 2, p. 233-290.

SOUZA, Laura de Mello e. Desclassificados do ouro: a pobreza mineira no século XVIII. Rio de Janeiro: Edições Graal, 2004. (Primeira edição em 1982).

TINHORÃO, José Ramos. As festas no Brasil colonial. São Paulo: Ed. 34, 2000.

VENÂNCIO, Renato Pinto. Compadrio e liberdade: a escolha de padrinhos entre ex-escravos de Ouro Preto colonial. Anais da V Jornada Setecentista, Curitiba, 2003. Mimeografado.

\section{RESUMO}

Este artigo analisa as relaçôes de compadrio tecidas em importante núcleo minerador no âmbito da América Portuguesa e levanta novas questôes sobre o tema. Através da história de livres, escravos e forros procura-se entender como a sociedade colonial institucionalizou práticas ao transgredir a norma eclesiástica que proibia a participação de pais como padrinhos dos próprios filhos. Além disso, a análise aponta como os vinculos entre compadres, padrinhos e afilhados produziram várias reciprocidades e como o apadrinhamento também se refletia em legados e bens deixados por aqueles que fizeram do compadrio prática de eleição de uma povoaçāo em processo de formação.

Palavras-chave: Brasil Colônia, escravidão, parentesco, compadrio.

\section{ABSTRACT}

This article analyzes the godparent relationships established in an important mining region in the Portuguese America and raises new questions about the topic. The story of free men, slaves and freed slaves helps to understand how colonial society institutionalized practices in violating the ecclesiastical rule that prohibits parents as godfathers of their own children. Furthermore, the analysis reveals how the ties between compadres, godfathers and godchildren produced reciprocity and cooperation and how the sponsorship custom results in legacies and material wealth for the population of a village in the process of formation.

Keywords: Colonial Brazil, slavery, family relationship, godparent relationship. 